CIVICS EDUCATION AND SOCIAL SCIENSE JOURNAL(CESSJ)

Volume 3 Nomor 1 Edisi Bulan Juni 2021

\title{
PENINGKATAN HASIL BELAJAR PKn MELALUI MODEL PEMBELAJARAN KOOPERATIF TIPE STUDENT TEAMS ACHIEVMENT DIVISION (STAD) DI KELAS V SDN 04 TANJUNG BATU
}

\author{
Anita \\ SDN 04 Tanjung Batu
}

\begin{abstract}
ABSTRAK
Tujuan dari penelitian ini adalah untuk meningkatkan hasil belajar siswa di kelas V pada SDN 04 Tanjung Batu dengan menggunakan model pembelajaran Student Teams Achievment Division (STAD). Subjek penelitian ini adalah siswa kelas V SDN 24 Tanjung Batu Kecamatan Tanjung Batu Kabupaten Ogan Ilir.

Model Student Teams Achievment Division adalah bagian dari model pembelajaran kooperatif, yang menekankan pada aktivitas dan interaksi diantara siswa untuk saling memotivasi dan saling membantu dalam menguasai materi pelajaran guna mencapai prestasi yang maksimal. Pembelajaran kooperatif tipe STAD terdiri dari lima komponen utama, yaitu penyajian kelas, belajar kelompok, kuis, skor pengembangan, dan penghargaan kelompok.

Model pembelajaran kooperatif tipe STAD dapat meningkatkan hasil belajar siswa kelas V SDN 04 Tanjung Batu. Peningkatan hasil belajar PKn dapat dilihat dari persentase ketuntasan belajar sebelum tindakan sebesar 56,67 \% terjadi peningkatan di siklus I pada pertemuan 1 menjadi $60 \%$ dengan rata-rata 62,97, pada siklus I pertemuan 2 mengalami peningkatan menjadi $63,33 \%$ dengan ratarata 64,17 . Pada siklus II juga mengalami peningkatan menjadi 70,00\% dengan rata-rata 67,38 , pada siklus III pertemuan 1 persentase ketuntasannya sebesar $80 \%$ dengan rata-rata 69,40 dan pada siklus III pertemuan 2 persentase ketuntasannya sebesar $86,67 \%$ dengan rata-rata 72,67 .

Model pembelajaran kooperatif tipe STAD ini juga meningkatkan keaktifan siswa, siswa berperan aktif dalam pembelajaran, tidak takut bertanya, melatih kerja sama, mendengarkan pendapat orang lain, kepedulian dan meningkatkan interaksi antar siswa. Peningkatan aktivitas siswa dapat dilihat dari hasil observasi pada siklus I pertemuan 1 sebesar 58,89\%, pada siklus I pertemuan 1 meningkat menjadi $61,67 \%$, pada siklus II sebesar 63,89, pada siklus III pertemuan 1 sebesar $67,78 \%$ dan pada siklus III pertemuan 2 sebesar $71,11 \%$.

Dengan demikian dapat disimpulkan bahwa pembelajaran dengan model pembelajaran Student Teams Achievment Divisiom dapat meningkatkan hasil belajar dan meningkatkan keaktifan belajar PKn di kelas V SD Negeri 04 Tanjung Batu.
\end{abstract}

Kata Kunci : Teams Achievement Division, Hasil Belajar. 
CIVICS EDUCATION AND SOCIAL SCIENSE JOURNAL(CESSJ)

Volume 3 Nomor 1 Edisi Bulan Juni 2021

\section{PENDAHULUAN}

Proses belajar dan hasil belajar siswa tidak saja ditentukan oleh struktur dan kurikulum, tetapi juga dipengaruhi oleh faktor guru dan siswa. Guru harus mampu menerapkan suasana belajar yang aktif, kreatif, efektif dan menyenangkan, penerapan metode dan model pembelajaran, penggunaan media pembelajaran dan pengelolaan kelas yang baik sangatlah penting. Proses pembelajaran yang menyenangkan dapat memotivasi siswa dalam belajar, pembelajaran menarik membuat tidak bosan. Sehingga untuk mencapai pembelajaran tersebut harus adanya perencanaan pembelajaran yang baik, perencanaan pembelajaran yang baik akan mendukung keberhasilan pengajaran.

Masalah utama dalam pembelajaran yang banyak ditemui adalah rendahnya hasil belajar siswa. Sebagian besar siswa kurang memahami dan cenderung tidak tertarik dengan pelajaran PKn karena pelajaran PKn dianggap hanya mementingkan hafalan. Berdasarkan observasi di kelas V SDN 04 Tanjung Batu didapatkan bahwa hasil belajar masih rendah dengan jumlah siswa 30 didapat data sebagai berikut 6 siswa terlampaui $(20,00 \%), 11$ siswa tercapai $(36,67 \%)$, dan 13 siswa tidak tercapai (43,33\%), siswa telah mencapai KKM 70 ada 17 siswa, secara klasikal persentase ketuntasan adalah 56,67 \%. Guru menggunakan metode ceramah yang diselingi dengan tanya jawab, sehingga sebagian besar siswa kurang termotivasi dalam belajar, guru merupakan sumber informasi utama, sebagian besar siswa pasif karena hanya menerima apa saja yang diberikan guru, siswa kurang aktif dalam bertanya atau memberikan pendapat, sehingga pembelajaran berlangsung satu arah. Akibatnya keaktifan siswa masih kecil dan menyebabkan rendahnya hasil belajar siswa.

Rendahnya hasil belajar PKn juga bisa disebabkan oleh faktor eksternal seperti pengelolaan kelas kurang baik, media pembelajaran kurang menarik bagi siswa, siswa tidak dilibatkan dalam proses pembelajaran dan metode serta model pembelajaran yang kurang tepat. Untuk mengatasi masalah diatas dapat dilatih dengan menggunakan model pembelajaran kooperatif salah satunya tipe Student Teams Achievement Devisions (STAD).

Slavin menyatakan bahwa pembelajaran kooperatif merupakan suatu model atau acuan pembelajaran dimana dalam proses pembelajaran yang berlangsung, siswa mampu belajar dan bekerja dalam kelompok-kelompok kecil secara kolaboratif yang anggotanya terdiri dari 4 sampai 6 orang, dengan struktur kelompoknya yang bersifat heterogen atau dengan karakteristik yang berbeda-beda. Guru sebagai perancang dan pelaksana pembelajaran kooperatif harus memperhatikan beberapa konsep dasar tentang pembelajaran kooperatif (Priansa, 2014: 243).

Pembelajaran model STAD dapat memotivasi dan membantu siswa dalam menguasi materi pembelajaran yang diberikan guru. Guru menyampaikan pembelajaran kemudian siswa bekerja dalam tim heterogen yang telah dibentuk untuk memastikan bahwa seluruh anggota tim menguasai pelajaran tersebut. Akhirnya seluruh siswa diberi kuis. Saat kuis, mereka tidak boleh saling membantu. 
CIVICS EDUCATION AND SOCIAL SCIENSE JOURNAL(CESSJ)

Volume 3 Nomor 1 Edisi Bulan Juni 2021

Langkah-langkah model pembelajaran STADyaitu: (1) Persentasi Kelas; (2) Tim; (3) Kuis; (4) Skor Individual; (5) Penghargaan Kelompok.

Inti dari STAD menurut Slavin adalah guru menyampaikan suatu materi, sementara para siswa tergabung dalam kelompoknya yang terdiri dari 4 atau 5 orang untuk menyelesaikan soal-soal yang diberikan oleh guru. Selanjutnya, siswa diberi kuis secara individual. Skor hasil kuis untuk menentukan skor individu juga digunakan untuk menentukan skor kelompoknya (Fathurrohman, Muhammad, 2015: 53).

Alasan peneliti memilih model STAD ini dirasakan tepat karena pembelajaran tidak lagi berpusat pada guru melainkan akan menciptakan pembelajaran dua arah, adanya interaksi antar siswa dengan siswa dan interaksi antara siswa dengan guru, siswa tidak takut bertanya dan berpendapat, siswa saling berbagi pengetahuan. STAD adalah suatu model pembelajaran yang melibatkan siswa untuk berperan aktif dalam pembelajaran dan menjadi salah satu solusi untuk mendorong siswa berpikir dan bekerja ketimbang menghafal. Hasil yang diharapkan dari pembelajaran model STAD adalah siswa lebih termotivasi dan berperan aktif dalam pembelajaran, meningkatkan penguasaan materi siswa sehingga hasil belajar meningkat.

Berdasarkan uraian diatas, maka peneliti akan melakukan penelitian dengan judul "Upaya meningkatkan hasil belajar PKn melalui model pembelajaran kooperatif tipe Student Teams Achievment Division (STAD) di kelas V SDN 04 Tanjung Batu". Tujuan penelitian ini untuk meningkatkan hasil belajar siswa pada pelajaran PKn di kelas V SDN 04 Tanjung Batu dengan menggunakan model pembelajaran koopertaif tipe Student Teams Achievment Division (STAD).

\section{METODE}

\section{Hasil Belajar}

Suyono dan Hariyanto (2011) memaknai belajar sebagai suatu proses perubahan perilaku akibat interaksi individu dengan lingkungan. Menurut Piaget, belajar merupakan pengetahuan yang dibentuk individu. Sebab individu melakukan interaksi terus-menerus dengan lingkungan. Lingkungan tersebut mengalami perubahan. Dengan adanya interaksi maka fungsi interaksi semakin berkembang (Dimyati dan Mudjiono, 2006).

\section{Pembelajaran Kooperatif Tipe Student Teams Achievment Division (STAD)}

Sanjaya menyatakan bahwa pembelajaran kooperatif merupakan model pembelajaran dengan menggunakan model pengelompokan/tim kecil, yaitu antara empat sampai enam orang yang mempunyai latar belakang kemampuan akademik, jenis kelamin, ras, atau suku yang berbeda (Priansa, 2014: 244). Pembelajaran kooperatif merupakan model pembelajaran yang mengutamakan kerjasama di antara siswa untuk mencapai tujuan pembelajaran. 
CIVICS EDUCATION AND SOCIAL SCIENSE JOURNAL(CESSJ)

Volume 3 Nomor 1 Edisi Bulan Juni 2021

Lokasi Penelitian adalah SD Negeri 04 Tanjung Batu beralamat di Jalan Sayid Makdum Kec. Tanjung Batu Kabupaten Ogan Ilir Provinsi Sumatera Selatan. Pengumpulan data dilakukan dengan menggunakan observasi dan tes. Teknik analisa data menggunakan rumus teknik proporsi dengan rumus : $\mathrm{D}=[\mathrm{A} / \mathrm{N}] \mathrm{x}$ $100 \%$

Dimana :

$\mathrm{D}$ :prosentase siswa yang tuntas

A :Jumlah siswa yang tuntas

$\mathrm{N}$ :Jumlah seluruh siswa (Sudjana, 2010)

Hasil analisis data disajikan dalam bentuk data, table dan grafik untuk memudahkan dalam membaca data dan memprediksi kesimpulan apa yang diambil dari penelitian yang dilakukan.

\section{HASIL PENELITIAN DAN PEMBAHASAN}

\section{Hasil Penelitian Peningkatan Hasil Belajar Siswa Akhir Siklus I Sampai Siklus III}

Proses pembelajaran yang dilakukan menggunakan model kooperatif tipe STAD mengarah kepada peningkatan keaktifan siswa, motivasi belajar siswa pun meningkat sehingga berpengaruh ke hasil belajar siswa. Peningkatan hasil belajar siswa mata pelajaran PKn dapat dilihat pada tabel berikut ini :

Tabel 24 : Data peningkatan hasil belajar siswa siklus I sampai siklus III

\begin{tabular}{|c|l|c|c|c|c|c|}
\hline No & \multicolumn{1}{|c|}{ Parameter } & $\begin{array}{c}\text { Siklus I } \\
\text { Per-1 }\end{array}$ & $\begin{array}{c}\text { Siklus I } \\
\text { Per-2 }\end{array}$ & Siklus II & $\begin{array}{c}\text { Siklus III } \\
\text { Per-1 }\end{array}$ & $\begin{array}{c}\text { Siklus III } \\
\text { Per- 2 }\end{array}$ \\
\hline 1 & Jumlah siswa & 30 & 30 & 30 & 30 & 30 \\
\hline 2 & Rata-rata & 62,97 & 64,17 & 67,38 & 69,40 & 72,67 \\
\hline 3 & Jumlah siswa yang tuntas & 18 & 19 & 21 & 24 & 26 \\
\hline 4 & $\begin{array}{l}\text { Jumlah siswa yang tidak } \\
\text { tuntas }\end{array}$ & 12 & 11 & 9 & 6 & 4 \\
\hline 6 & $\begin{array}{l}\text { Persentase jumlah siswa } \\
\text { yang tuntas }\end{array}$ & $60,00 \%$ & $63,33 \%$ & $70,00 \%$ & $80,00 \%$ & $86,67 \%$ \\
\hline
\end{tabular}


CIVICS EDUCATION AND SOCIAL SCIENSE JOURNAL(CESSJ)

Volume 3 Nomor 1 Edisi Bulan Juni 2021

Pada siklus I pertemuan 1 jumlah siswa yang tuntas mencapai KKM 70 adalah 18 siswa dengan persentase klasikal 60,00 \% dengan rata-rata 62,97, siklus I pertemuan 2 ada 19 siswa yang tuntas dengan persentase $63,33 \%$ dan rata-rata 64,17 , pada siklus II jumlah siswa yang tuntas adalah 21 siswa dengan persentase ketuntasan klasikal adalah 70,00 \% dengan rata-rata 67,38, pada siklus III pertemuan 1 ketuntasan belajar siswa sebesar $80,00 \%$ sebanyak 24 siswa dengan rata-rata 69,40 dan pada siklus III pertemuan 2 ketuntasan belajar siswa dengan persentase $86,67 \%, 26$ siswa yang tuntas dengan rata-rata 72,67.

Indikator keberhasilan penelitian ini adalah $85 \%$ siswa mencapai KKM 70 sedangkan dalam penelitian ini 86,67 \% siswa telah mencapai KKM jadi penelitian ini telah berhasil meningkatkan hasil belajar PKn siswa kelas V SDN 12 Tanjung batu melalui pembelajaran Kooperatif Tipe STAD.

Tabel 25 : Peningkatan Hasil Belajar

\begin{tabular}{|c|c|c|}
\hline Penelitian & Tuntas (\%) & Tidak Tuntas (\%) \\
\hline Pra penelitian & $56,67 \%$ & $43,33 \%$ \\
\hline Siklus I Per -1 & $60,00 \%$ & $40,00 \%$ \\
\hline Siklus I Per -2 & $63,33 \%$ & $36,67 \%$ \\
\hline Siklus II & $70,00 \%$ & $30,00 \%$ \\
\hline Siklus III Per-1 & $80,00 \%$ & $20,00 \%$ \\
\hline Siklus III Per-2 & $86,67 \%$ & $13,33 \%$ \\
\hline
\end{tabular}

Berdasarkan tabel diatas, dapat dilihat belajar secara klasikal pra penelitian $56,67 \%$ mengalami peningkatan pada siklus I pertemuan 1 menjadi $60,00 \%$, pada siklus I pertemuan ke 2 meningkat menjadi 63,33\%, pada siklus II meningkat menjadi 70,00\%, pada siklus III pertemuan 1 terjadi peningkatan menjadi 80,00 $\%$ dan ke siklus III pertemuan 2 juga mengalami peningkatan menjadi $86,67 \%$, jadi pembelajaran dengan menggunakan model pembelajaran kooperatif tipe STAD dinyatakan berhasil karena sudah mencapai ketuntasan diatas $85 \%$ yaitu $86,67 \%$.

Peningkatan hasil belajar dengan menerapkan model kooperatif tipe STAD ini dapat membantu siswa dalam proses pembelajaran, siswa tidak takut bertanya dan berpendapat, adanya interaksi dan kerja sama antar siswa dan melatih siswa untuk menghargai dan mendengarkan pendapat orang lain. Dengan demikian 
CIVICS EDUCATION AND SOCIAL SCIENSE JOURNAL(CESSJ)

Volume 3 Nomor 1 Edisi Bulan Juni 2021

tampak bahwa pembelajaran kooperatif tipe STAD dapat meningkatkan hasil belajar siswa pada pelajaran PKn. Secara rinci dapat dilihat pada gambar dibawah ini :

Gambar 12: Grafik Peningkatan Hasil Belajar

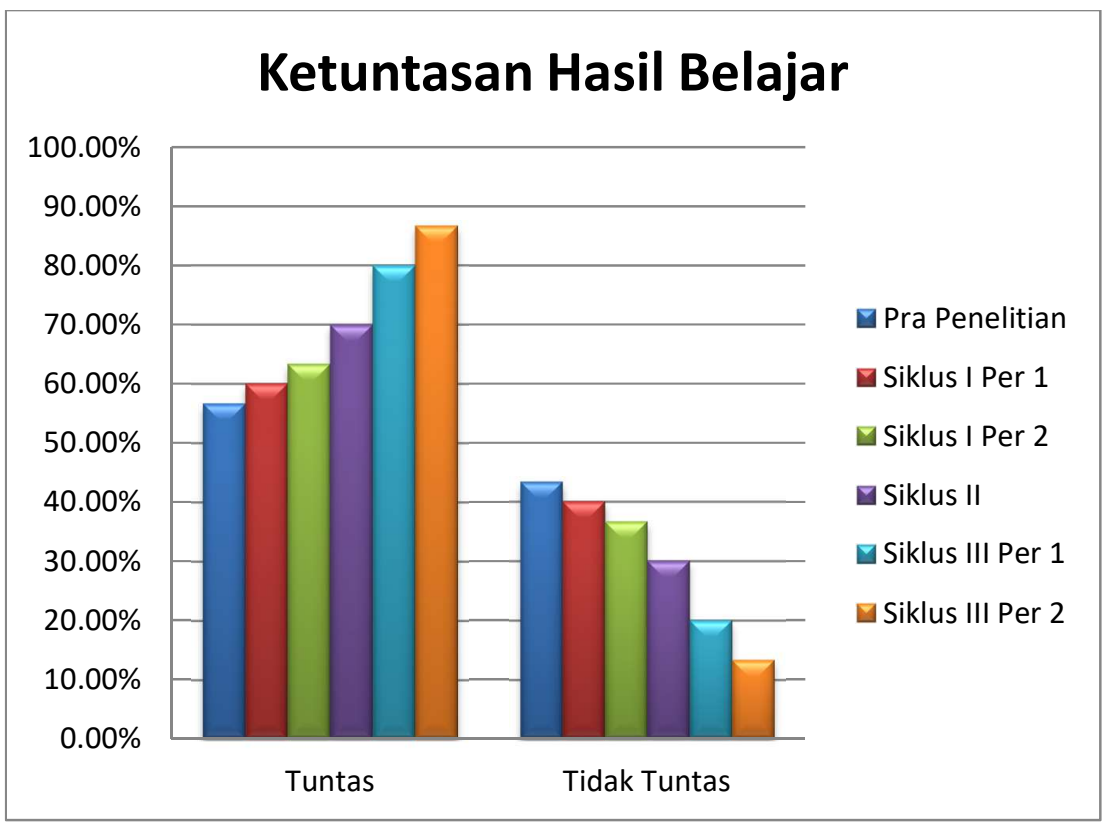

Pada gambar 12 diatas menunjukkan bahwa persentase ketuntasan klasikal yang dicapai meningkat setiap siklusnya.

2. Peningkatan Aktivitas Belajar Siswa Akhir Siklus I sampai siklus III Aktivitas belajar siswa pada siklus I sampai siklus III dapat dilihat pada tabel berikut ini :

Tabel 26 : Data persentase Peningkatan Aktivitas Belajar Siswa pada Siklus I dan Siklus III 
CIVICS EDUCATION AND SOCIAL SCIENSE JOURNAL(CESSJ)

Volume 3 Nomor 1 Edisi Bulan Juni 2021

\begin{tabular}{|c|l|c|c|c|c|c|}
\hline No & \multicolumn{1}{|c|}{ Aktivitas Siswa } & $\begin{array}{c}\text { Siklus } \\
\text { I Per 1 }\end{array}$ & $\begin{array}{l}\text { Siklus } \\
\text { I Per 2 }\end{array}$ & $\begin{array}{l}\text { Siklus } \\
\text { II }\end{array}$ & $\begin{array}{c}\text { Siklus III } \\
\text { Per 1 }\end{array}$ & $\begin{array}{c}\text { Siklus III } \\
\text { Per 2 }\end{array}$ \\
\hline 1 & $\begin{array}{l}\text { Siswa memperhatikan apa } \\
\text { yang di sampaikan guru }\end{array}$ & 66,67 & 63,33 & 63,33 & 66,67 & 70,00 \\
\hline 2 & $\begin{array}{l}\text { Siswa bekerja sama } \\
\text { dengan anggota kelompok }\end{array}$ & 56,67 & 56,67 & 60,00 & 66,67 & 66,67 \\
\hline 3 & $\begin{array}{l}\text { Siswa menjawab } \\
\text { pertanyaan }\end{array}$ & 60,00 & 66,67 & 66,67 & 63,33 & 66,67 \\
\hline 4 & $\begin{array}{l}\text { Siswa mengajukan } \\
\text { pendapat }\end{array}$ & 53,33 & 63,33 & 63,33 & 63,33 & 70,00 \\
\hline 5 & $\begin{array}{l}\text { Siswa menanggapi } \\
\text { pendapat teman }\end{array}$ & 50,00 & 53,33 & 56,67 & 66,67 & 70,00 \\
\hline 6 & $\begin{array}{l}\text { Siswa mencatat } \\
\text { kesimpulan }\end{array}$ & 66,67 & 66,67 & 73,33 & 80,00 & 83,33 \\
\hline & Persentase (\%) & 58,89 & 61,67 & 63,89 & 67,78 & 71,11 \\
\hline
\end{tabular}

Berdasarkan tabel diatas rata-rata setiap aktivitas siswa mengalami peningkatan, pada siklus I pertemuan 1 dengan persentase 58,89\% (Cukup), pada siklus I pertemuan 2 terjadi peningkatan menjadi 61,67 (Cukup), pada pertemuan siklus II juga mengalami peningkatan menjadi 63,89 (Cukup), pada pertemuan selanjutnya yaitu siklus III pertemuan 1 persentasenya 67,78 \% (Baik) dan pada pertemuan terakhir siklus III pertemuan 2 mengalami peningkatan menjadi 71,11\% (Baik). Peningkatan aktivitas belajar siswa tersebut digambarkan dalam gambar berikut :

Gambar 13: Grafik Persentase Peningkatan Aktivitas Belajar Siswa pada Siklus I sampai Siklus III 


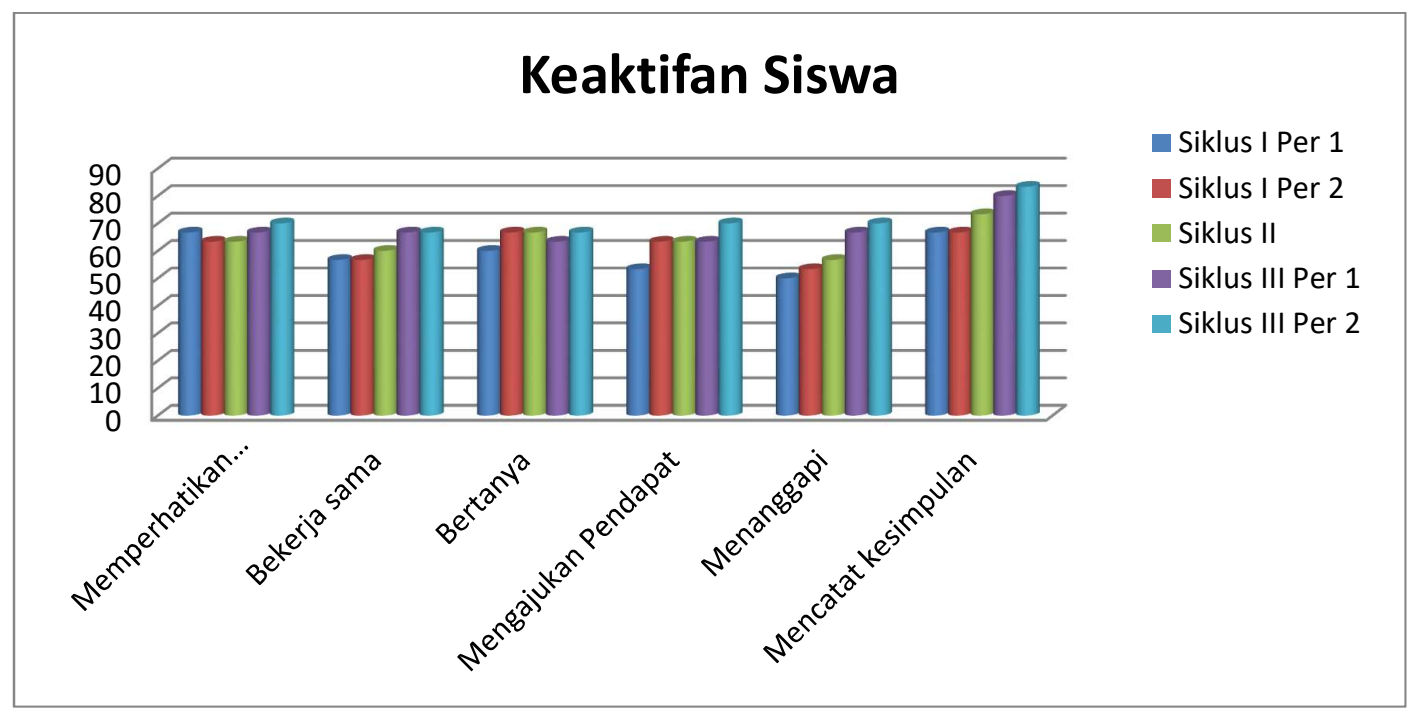

Pada gambar 13 di atas, menunjukkan bahwa peningkatan aktivitas belajar siswa dari siklus I ke siklus III rata-rata mengalami peningkatan, hal ini menunjukan bahwa : Keaktifan siswa dalam pembelajaran sudah baik dan siswa sudah terlatih mengikuti pembelajaran kooperatif tipe STAD, interaksi antar siswa dalam proses pembelajaran sudah baik, siswa tidak hanya menunggu dalam pembelajaran, namun siswa berperan aktif dalam proses pembelajaran.

Dari data yang telah dibahas diperoleh kesimpulan bahwa "Pembelajaran menggunakan model pembelajaran kooperatif tipe STAD dapat meningkatkan hasil belajar pada mata pelajaran Pendidikan Kewarganegaraan di kelas V di SDN 04 Tanjung Batu".

Hasil penelitian ini mendukung penelitian yang telah lebih dulu dilaksanakan oleh Subiarto melakukan Penelitian Tindakan Kelas tentang "Upaya Meningkatkan Minat dan Prestasi Belajar PKn Materi PEMILU dan PILKADA Melalui Metode Pembelajaran Kooperatif Model STAD Bagi Siswa Kelas VI SDN Kalilunjar pada Semester 1 Tahun Pelajaran 2012/2013". Kesimpulan dari penelitian ini adalah bahwa penerapan pembelajaran koopertif tipe STAD dalam pembelajaran dapat meningkatkan minat dan prestasi belajar siswa di kelas VI SDN Kalilunjar tahun pelajaran 2012-2013.

Hasil penelitian ini senada dengan penelitian yangdilakukan Miswadi, Dasa Ismaimuza, dan I Nyoman Murdianatentang "Penerapan Model Pembelajaran Kooperatif Tipe STAD pada Luas Persegi dan Persegi Panjang di Kelas IV SD Inpres 2 Slametharjo". Kesimpulan dari penelitian ini adalah pembelajaran menggunakan model pembelajaran kooperatif tipe STAD dapat meningkatkan hasil belajar dan aktivitas siswa.

Hasil penelitian ini senada pula menurut pendapat Donni Priansa (2014) yang mengemukakan bahwa pembelajaran menggunakan kooperatif tipe STAD siswa bekerja sama, aktif berperan sebagai tutor sebaya, peningkatan interaksi antar siswa dan siswa akan aktif membantu dan memotivasi semangat untuk berhasil bersama dalam pembelajaran.

JORNAL PROGDI PPKn, FKIP UNIVET BANTARA SUKOHARJO BEKERJA SAMA DENGAN ASSOSIASI PROFESI PENDIDIKAN PANCASILA DAN KEWARGANEGARAAN (AP3KNI) JAWA TENGAH 
CIVICS EDUCATION AND SOCIAL SCIENSE JOURNAL(CESSJ)

Volume 3 Nomor 1 Edisi Bulan Juni 2021

\section{SIMPULAN}

Model pembelajaran kooperatif tipe STAD dapat meningkatkan hasil belajar siswa kelas V SDN 04 Tanjung Batu. Peningkatan hasil belajar PKn dapat dilihat dari persentase ketuntasan belajar sebelum tindakan sebesar 56,67 \% terjadi peningkatan di siklus I pada pertemuan 1 menjadi $60 \%$ dengan rata-rata 62,97, pada siklus I pertemuan 2 mengalami peningkatan menjadi $63,33 \%$ dengan ratarata 64,17 . Pada siklus II juga mengalami peningkatan menjadi 70,00\% dengan rata-rata 67,38 , pada siklus III pertemuan 1 persentase ketuntasannya sebesar $80 \%$ dengan rata-rata 69,40 dan pada siklus III pertemuan 2 persentase ketuntasannya sebesar $86,67 \%$ dengan rata-rata 72,67 .

Model pembelajaran kooperatif tipe STAD ini juga meningkatkan keaktifan siswa, siswa berperan aktif dalam pembelajaran, tidak takut bertanya, melatih kerja sama, mendengarkan pendapat orang lain, kepedulian dan meningkatkan interaksi antar siswa. Peningkatan aktivitas siswa dapat dilihat dari hasil observasi pada siklus I pertemuan 1 sebesar 58,89\%, pada siklus I pertemuan 1 meningkat menjadi $61,67 \%$, pada siklus II sebesar 63,89, pada siklus III pertemuan 1 sebesar $67,78 \%$ dan pada siklus III pertemuan 2 sebesar 71,11\%.

Berdasarkan penelitian yang dilakukan, penerapan model pembeajaran kooperatif tipe STAD dapat meningkatkan hasil belajar dan keaktifan siswa. Guru disarankan menggunakan model pembelajaran ini untuk memperbaiki permasalahan yang sama di dalam kelas. Sebelum melaksanakan pembelajaran.

\section{REFERENSI}

Dimyati dan Mudjiono. 2006. Belajar dan Pembelajaran. Jakarta : PT Rineka Cipta.

Peraturan Menteri Pendidikan Nasional Nomor 22 Tahun 2006 tentang Standar Isi. Jakarta : Depdiknas.

Priansa, Donni. 2014. Manajemen Peserta Didik dan Model Pembelajaran. Bandung : Alfabeta Bandung.

Suyono dan Haryanto. 2010. Belajar dan Pembelajaran Teori dan Konsep Dasar. Bandung : Remaja Rosdakarya. 